\title{
Analisis Rasio Efektivitas PAD Terhadap Kinerja Keuangan Daerah Kota Jakarta Periode 2015-2019
}

\author{
${ }^{1}$ Arya Putra Supriyadi, ${ }^{2}$ Fandi Ahmad \\ ${ }^{1,2}$ Politeknik Sekolah Tinggi Ilmu Administrasi Lembaga Administrasi Negara Bandung \\ e-mail : aryaputrasupriyadi@gmail.com
}

\begin{abstract}
Abstrak - Saat ini setiap organisasi berupaya untuk menjaga performa dalam rangka memenangkan persaingan, dan untuk mengetahui kemajuan dari organisasi dapat dilihat dengan memperhatikan kinerja keuangan, penelitian ini mencoba untuk menelaah dan menilai kinerja keuangan Pemerintah Kota Jakarta periode anggaran 2015 -2019 dengan memanfaatkan hasil telaah rasio Pendapatan Asli Daerah (PAD), serta rasio efektivitas PAD didalam Laporan mengenai realisasi yang terkandung dalam Anggaran Pendapatan dan Belanja Daerah (APBD) Pemerintah Daerah Kota Jakarta. Dengan memanfaatkan sumber data berupa Laporan Realisasi Anggaran pada periode anggaran 2015-2019 yang berlandaskan Laporan Keuangan Pemerintah Daerah (LKPD) Pemerintah Daerah Kota Jakarta. Penelitian ini menggunakan teknik pendekatan metode mix methode yaitu peneliti mencoba menelaah data keuangan untuk selanjutnya mencoba untuk mendeskripsikan temuan yang ada. Dari hasil penelitian diketahui bahwa perhitungan rasio efektivitas yaitu dengan membagi jumlah realisasi dari PAD dibandingkan dengan dengan target PAD yang ditetapkan berasaskan potensi nyata pada daerah, Atau dengan kata lain Rasio efektivitas PAD didapatkan dengan melakukan perbandingan antara penerimaan riil pada PAD dengan tujuan capaian PAD (dianggarkan). Dari pengolahan data diketahui, besaran pesentase efektivitas PAD Kota Jakarta tahun anggaran 2015-2019 rata-rata tingkat pencapaiannya telah mencapai 95,4\% dari besaran yang ditentukan atau dapat dikatakan telah mencapai kategori kriteria efektif.
\end{abstract}

Kata Kunci: Rasio efektivitas, LKPD Jakarta, Pendapatan Asli Daerah (PAD)

\begin{abstract}
Currently, every organization seeks to maintain performance in order to win the competition, and find out the progress of the organization can be seen by paying attention to financial performance, this study tries to examine and assess the financial performance of the Jakarta City Government for the 2015-2019 budget period by utilizing the results of the review of the Original Income ratio. Regions (PAD), as well as the effectiveness ratio of PAD in the report regarding the realization contained in the Regional Budget (APBD) of the Regional Government of the City of Jakarta. By utilizing a data source in the form of a Budget Realization Report for the 2015-2019 budget period which is based on the Regional Government Financial Report (LKPD) of the Jakarta City Government. This study uses a mixed-method approach technique, namely the researcher tries to analyze financial data to further attempt to describe the existing findings. From the research results, it is known that the calculation of the effectiveness ratio is by dividing the amount of realization of PAD compared to the target PAD set based on the real potential in the region, or in other words, the effectiveness ratio of PAD is obtained by making a comparison between real revenue in PAD to achieve PAD ). From data processing, it is known that the percentage of effectiveness of PAD in the City of Jakarta for the 2015-2019 budget year has reached an average level of achievement of $95.4 \%$ of the determined amount or it can be said that it has reached the category of effective criteria.
\end{abstract}

Keywords: effectiveness ratio, LKPD Jakarta, Regional Original Income (PAD)

\section{PENDAHULUAN}

Perubahan kepemimpinan di Negara manapun, biasanya selalu mengubah tata kelola keuangan Negara tersebut. Tidak terkecuali di Negara Indonesia tersendiri, sejak pasca era reformasi, Indonesia menggalakan dan memberlakukan tata kelola keuangan secara otonomi daerah yang luas. Dengan kata lain hal tersebut mengubah pola pemikiran dan pandangan masyarakat Indonesia mengenai tata kelola keuangan Negara, karena era sebelum reformasi, yaitu era Soeharto, kepemimpinan beliau yaitu membuat kebijakan menutup defisit anggaran menggunakan hutang luar negeri. Perubahan tata kelola ini bisa dilihat dari adanya kebijakan otonomi daerah dan dana yang bersumber dari APBN keuangan pemerintah pusat maupun yang bersumber dari pemerintah daerah yang diatur dalam UU No.25 Tahun 1999 mengenai dana yang bersumber dari pendapatan APBN yang 
dialokasikan untuk Keuangan pemerintah Pusat maupun terhadap keuangan Pemerintah Daerah. Selain itu diperkuat dengan adanya Peraturan Menteri Dalam Negeri No.13 Tahun 2013 pasal 3 mengenai kemampuan pemerintah dalam mengelola keuangan daerah, dasar-dasar umum dan pengorganisasian unsur-unsur dalam APBD.

Adanya Otonomi Daerah juga memberikan wewenang pada setiap daerah dalam mengelola pemerintahan dan pembangunan daerahnya sebagaimana Undang-Undang Nomor 9 Tahun 2015 Tentang Perubahan Kedua atas Undang-Undang Nomor 23 Tahun 2014 yang menjelaskan mengenai Pemerintahan Daerah sehingga semua daerah memiliki kesempatan guna meningkatkan pembangunan melalui inovasi, dan juga dapat menciptakan daya saing dalam tata kelola ekonomi daerah. Dalam merealisasikan sistem otonomi daerah, tingkat kemandirian dalam pengelolaan keuangan yang tinggi sangat diharapkan kepada pemerintah daerah. Jika tingkat atau tahap dari kemandirian pengelolaan keuangan yang tinggi dapat diartikan bahwa daerah bisa dikatakan tidak mesti bergantung terhadap bantuan pemerintah pusat maupun provinsi melalui perimbangan. Tetapi, belum tentu jika tingkat atau tahap dari kemandirian keuangan daerah tinggi alhasil bisa dikatakan daerah tersebut tidak mesti memerlukan dana yang bersumber dari pendapatan APBN. Karena dana yang bersumber dari pendapatan APBN akan tetap dibutuhkan guna melakukan percepatan dalam membina daerah, dengan kata lain semakin tinggi tingkat atau tahap dari kemandirian daerah alhasil daerah akan mampu menyediakan reparasi publik yang bermutu . dengan adanya publikasi dari pemerintah daerah mengenai pembuatan Laporan Realisasi Anggaran jelas akan memberi informasi berguna untuk mengukur kinerja dari pengelolaan keuangan oleh pemerintah daerah. sebab itu, penelitian ini bermaksud guna mengetahui dan menilai seberapa efektif rancangan anggaran terhadap Pendapatan Asli Daerah (PAD) jika dibanding dengan realisasi Pendapatan Asli Daerah Pemerintah DKI Jakarta. Atau dengan kata lain berada ditingkat manakah keefektifan pengelolaan keuangan daerah Pemerintah DKI Jakarta pada periode tahun 2015 2019. Untuk mengukur keefektifitasan pengelolaan keuangan sebuah daerah, perhitungannya dapat memakai rumus rasio efektifitas yang dihitung menggunakan cara membagi jumlah realisasi Pendapatan Asli Daerah (PAD) dibandingkan dengan dengan target PAD yang telah ditetapkan berlandaskan potensi riil daerah (Halim \& Kusufi,
2007). Rasio efektifitas keuangan Kota DKI Jakarta ini dimaksudkan untuk membahas sebesar apa efektifitas dari kegiatan Keuangan yang dilakukan Pemerintah DKI Jakarta.

\section{METODE PENELITIAN}

Dalam penulisan penelitian ini bertujuan guna mendeskripsikan capaian kinerja dari sisi keuangan daerah Kota DKI Jakarta tiap periode dengan menghitung rasio efektifitas pendapatan asli daerah (PAD). sehingga dari perhitungan tersebut didapati tingkat Efektifitas dan kualitas kinerja keuangan daerah kota DKI Jakarta. Sumber data pada penelitian berlandaskan Laporan mengnai Keuangan Pemerintah Daerah (LKPD) DKI Jakarta. representatif yang diambil yaitu LKPD DKI Jakarta yang dipublikasikan dalam kurun waktu lima tahun belakang dimulai dari 2015 hingga 2019. Metode dari data yang dikumpulkan dalam penelitian bersumber pada data sekunder. dimana data sekunder merupakan suatu kumpulan data yang diperoleh dari pihak lain (Kuncoro, 2009). Data yang diolah berwujud laporan keuangan pemerintah daerah yang tersedia dalam laman resmi LKPD Kota DKI Jakarta. Metode analisis penelitian ini menggunakan pendekatan mix methode dimana didalamnya mencoba mengolah data statistik yang dipakai guna menganalisa untuk selanjutnya mencoba mendeskripsikan hasil dari temuan dan pengolahan data (Sugiyono, 2004).

\section{HASIL DAN PEMBAHASAN}

Pendapatan Asli Daerah menurut Mardiasmo (Mardiasmo, 2002), adalah suatu daerah yang memperoleh sumber dana yang berlandaskan pada peraturan daerah sesuai undang-undang, yang sumbernya didapatkan dari sektor pajak, retribusi, serta hasil dari PEMDA, hasil aktiva daerah terpisahkan, juga pendapatan lain-lain dari daerah merupakan pendapatan asli yang legal (contohnya adalah jumlah penjualan dari aset daerah yang tidak dipisahkan, pelayanan giro, dana yang bersumber dari bunga, hasil keuntungan antar nilai tukar mata uang (rupiah dengan asing), serta fee atau bonus, potongan, maupun wujud lain yang merupakan sebab atas jasa oleh daerah dan penyediaan logistik dan/atau penjualan). Harun Hamrolie (Harun, 1990) menjelaskan bahwa aspek-aspek yang dapat mempengaruhi PAD yaitu berasal dari bidang pajak daerah, seperti :kemampuan wajib pajak, besaran pajak yang dialokasikan, tarif pajak, serta dasar pajak. 
Undang- undang yang mengatur pajak serta retribusi Daerah tercantum pada UU No.34 Tahun 2000, yang termasuk dalam UU ini ialah jenis pajak daerah propinsi, seperti: Pajak bahan bakar Kendaraan Bermotor, Pajak Pengambilan dan Pemanfaatan Air Bawah Tanah dan Air Permukaan, Pajak Kendaraan Bermotor dan Kendaraan diatas Bea
Balik Nama Kendaraan Bermotor dan Kendaraan diatas Air. Serta tipe pajak daerah, seperti: Pajak hotel, hiburan reklame, restoran, pengambilang bahan galian gol.C, penerangan jalan dan pajak parkir. Sedangkan untuk mengatur jenis-jenis pendapatan daerah yang sah diatur pada UU No 32 tahun 2004 pasal 157.

Tabel 1. LKPD Kota Jakarta 2015-2019

\begin{tabular}{|c|c|c|c|c|c|c|}
\hline Tahun & Pajak Daerah & Retribusi Daerah & $\begin{array}{c}\text { Hasil Pengelolaan } \\
\text { Asset yang } \\
\text { Dipisahkan }\end{array}$ & $\begin{array}{c}\text { lain-lain Pendapatan } \\
\text { Asli Daerah Yang } \\
\text { Sah }\end{array}$ & $\begin{array}{c}\text { Pendapatan Asli } \\
\text { Daerah }\end{array}$ & $\begin{array}{c}\text { peningk } \\
\text { atan }\end{array}$ \\
\hline 2015 & 29.076 .926 .598 .506 & 459.459 .498 .063 & 527.280 .486 .037 & 3.622 .510 .233 .102 & 33.686 .176 .815 .708 & \\
\hline 2016 & 31.613 .197 .634 .662 & 675.475 .066 .072 & 303.204 .423 .956 & 4.296 .140 .463 .026 & 36.888 .017 .587 .716 & $9,50 \%$ \\
\hline 2017 & 36.500 .782 .266 .176 & 624.137 .343 .759 & 489.478 .684 .673 & 6.287 .090 .513 .134 & 43.901 .488 .807 .742 & $19,01 \%$ \\
\hline 2018 & 37.538 .912 .327 .312 & 578.555 .603 .994 & 592.956 .276 .353 & 4.616 .712 .395 .152 & 43.327 .136 .602 .811 & $-1,30 \%$ \\
\hline 2019 & 40.298 .122 .505 .326 & 587.384 .031 .230 & 619.456 .466 .460 & 4.202 .437 .000 .786 & 45.707 .400 .003 .802 & $5,50 \%$ \\
\hline
\end{tabular}

Sumber : Data Resmi LKPD Kota Jakarta 2015-2019 (data olahan)

\section{Penerimaan PAD Kota DKI Jakarta Tahun Anggaran (2015-2019)}

Berdasarkan analisis, PAD Kota DKI Jakarta dalam kurun waktu 5 tahun terakhir (2015-2019), menunjukkan peningkatan pertumbuhan yang sangat kecil, bahkan pernah terjadi penurunan. Di tahun 2016 meningkat sebesar 9,50\%. Di tahun 2017 meningkat kembali menjadi $19,01 \%$. Tetapi, Di tahun 2018 mengalami penurunan sebesar $1,30 \%$. Terakhir di tahun 2019 meningkat kembali dengan jumlah yang kecil sebesar 5,50\%. Ini menandakan bahwa dalam 5 tahun terakhir, Pendapatan Asli Daerah kota DKI Jakarta belum pernah mencapai peningkatan persentase lebih besar $20 \%$. Pendapatan daerah dari sumber lain berasal dari dana yang bersumber dari pendapatan APBN serta dana sumber lain-lain yang sah. Dana yang bersumber dari pendapatan APBN berasal dari dana bagi hasil pajak atau bagi hasil bukan pajak, dana alokasi umum, dan dana alokasi khusus. Sedangkan pendapatan lain-lain daerah yang sah berasal dari dana darurat, dana bagi hasil pajak dari provinsi dan Pemda lainnya, dana penyesuaian dan otonomi khusus serta dana hibah.

Rasio efektifitas pengelolaan Keuangan daerah bisa diukur menggunakan rumus sebagai berikut

\section{Rasio Efektifitas}

$$
\begin{aligned}
& =\frac{\text { Realisasi Penerimaan } P A D}{\text { Target Penerimaan PAD }} \\
& \times 100 \%
\end{aligned}
$$

Sumber : (Halim \& Kusufi, 2007)

Rasio efektifitas dihitung dengan membagi jumlah realisasi Pendapatan Asli Daerah (PAD) dibagi dengan target Pendapatan Asli Daerah (PAD) yang ditetapkan berlandaskan kemampuan riil daerah (Halim \& Kusufi, 2007). Atau dengan kata lain Rasio efektivitas PAD diukur menggunakan rumus membandingkan realisasi penerimaan PAD dibagi target penerimaan PAD (dianggarkan). Tujuan mengukur Rasio Efektivitas PAD sendiri adalah guna memperlihatkan kemampuan pelaksanaan pemerintah daerah dalam hal mengerahkan pemasukan PAD sesuai apa yang menjadi target awal. Kemampuan daerah untuk melaksanakan tugas dikategorikan efektif jika rasio yang tercapai minimal persentase nya sebesar 1 (satu) atau 100 persen. Semakin tinggi persentase dari rasio efektifitas menunjukkan kemampuan daerah dalam mengelola keuangan yang semakin baik. berikut merupakan referensi untuk melihat persentase dan kriteria tingkat rasio efektivitas keuangan daerah yang terdiri dari lima kriteria yaitu, kriteria tidak efektif, kurang efektif, cukup efektif, efektif dan sangat efektif

Tabel 2. Persentase Kinerja Keuangan

\begin{tabular}{cc}
\hline $\begin{array}{c}\text { Persentase Kinerja } \\
\text { Keuangan }\end{array}$ & Kriteria \\
\hline Diatas 100\% & Sangat Efektif \\
\hline $90 \%-100 \%$ & Efektif \\
\hline $80 \%-90 \%$ & Cukup Efektif \\
\hline $60 \%-80 \%$ & Kurang Efektif \\
\hline Kurang dari 60\% & Tidak Efektif \\
\hline $\begin{array}{c}\text { Sumber : (Munir, 2004) } \\
\text { Berdasarkan data yang diperoleh dari LKPD }\end{array}$
\end{tabular}

Kota Jakarta tahun 2015-2019. Berikut adalah data Target dan Realisasi PAD Kota Jakarta tahun 20152019 dan hasil dari perhitungan rasio efektifitas setiap tahunnya : 
Tabel 3. Rasio Efektifitas

\begin{tabular}{lllc}
\hline $\begin{array}{l}\text { Tahun } \\
\text { Anggar } \\
\text { an }\end{array}$ & Realisasi PAD & Target PAD & $\begin{array}{l}\text { Rasio } \\
\text { Efektifi } \\
\text { tas }\end{array}$ \\
\hline 2015 & 33.686 .176 .81 & 37.965 .616 .30 & $\begin{array}{c}88,73 \\
\%\end{array}$ \\
& 5.708 & 4.000 & \\
\hline 2016 & 36.888 .017 .58 & 38.501 .784 .83 & 95,81 \\
& 7.716 & 9.738 & $\%$ \\
\hline 2017 & 43.901 .488 .80 & 41.687 .387 .82 & 105,31 \\
& 7.743 & 6.535 & $\%$ \\
\hline 2018 & 43.327 .136 .60 & 44.350 .077 .85 & $97,7 \%$ \\
& 2.811 & 8.844 & \\
\hline 2019 & 45.707 .400 .00 & 50.845 .081 .89 & $89,9 \%$ \\
& 3.802 & 1.466 & \\
\hline Rata- & 203.510 .219 .8 & 213.349 .948 .7 & $95,4 \%$ \\
rata & 17.780 & 20.583 & \\
\hline Sumber $:$ Data Olahan 2020 & & \\
&
\end{tabular}

Sumber : Data Olahan 2020

Berdasarkan analisis, tingkat efektifitas PAD

Pemerintah Kota Jakarta tahun anggaran 2015-2019 dapat diuraikan, yaitu :

1. Di tahun 2015, rasio efektivitas Kota Jakarta persentase nya sebesar $88,73 \%$. Kinerja keuangan Kota Jakarta bersumber pada rasio efektivitas PAD masuk ke dalam golongan cukup efektif karena berada pada kisaran $80 \%-90 \%$. Hal ini menunjukkan pencapaian PAD tahun 2015 cukup mendekati target yang telah direncanakan, hanya selisih sebesar Rp 4.279.439.488.292. Realisasi PAD di tahun 2015 sebesar Rp 33.686.176.815.708, sedangkan target yang ditetapkan sebesar Rp 37.965.616.304.000.

2. Di tahun 2016, rasio efektivitas Kota Jakarta mengalami peningkatan sebesar 7,08 \% jika dibandingkan tahun 2015, yaitu menjadi 95,81\%. Kinerja keuangan Kota Jakarta di tahun 2016 bersumber pada rasio efektivitas PAD masuk kedalam golongan efektif karena berada pada kisaran 90\%-100\% . Realisasi PAD Kota Jakarta berhasil kembali mendekati target PAD yang sudah direncakan berasaskan peraturan daerah sebesar Rp 36.888.017.587.716 dari total target anggaran PAD sebesar Rp 38.501.784.839.738. Realisasi PAD pada tahun ini mengalami peningkatan sebesar $9,50 \%$ jika dibandingkan dengan tahun 2015 dan anggaran yang sudah dialokasikan juga meningkat sebesar $1,4 \%$ dari tahun 2015.

3. Di tahun 2017, rasio efektivitas Kota Jakarta persentasenya $105,31 \%$ atau mengalami peningkatan 9,5\% dari tahun 2016. Kota Jakarta sukses merealisasikan PAD lebih besar Rp 2.214.100.981.208 atau dengan kata lain melampaui target yang sudah direncanakan.
Kinerja keuangan Kota Jakarta di tahun ini bersumber pada efektivitas PAD masuk ke dalam golongan sangat efektif, karena persentase rasio nya melampaui $100 \%$.

4. Di tahun 2018, rasio efektivitas Kota Jakarta persentasenya 97,7\% dengan kata lain menurun 7,61\% dari tahun 2017. Dapat diartikan bahwa Kinerja Kota Jakarta tahun 2018 menurun diakibatkan realisasi PAD tidak kembali melampaui target yang ditetapkan, meskipun hampir menyamai target yaitu selisih sebesar Rp 1.022.941.256.033. sehingga kinerja keuangan Kota Jakarta di tahun 2018 bersumber pada rasio efektivitas masuk kedalam golongan efektif, karena berada dalam kisaran 90\%-100\%.

5. Di tahun 2019, rasio efektivitas Kota Jakarta kembali turun 7,8 \% dari tahun 2018, yaitu menjadi 89.9\%. PAD Kota Jakarta tahun 2019 yang terealisasi sebesar Rp 45.707.400.003.802, realisasi tersebut meningkat sebesar $\mathrm{Rp}$ 2.380.263.400.991 atau dalam persentase meningkat 5,5\% dari realisasi PAD tahun 2018. Selain itu, target yang sudah dialokasikan Kota Jakarta juga meningkat sebesar 14,64\% dari tahun 2018, menjadi sebesar Rp 50.845.081.891.466. Kinerja keuangan Kota Jakarta di tahun ini bersumber pada efektivitas PAD masuk kedalam golongan cukup efektif, karena berada di kisaran $80 \%-90 \%$

\section{KESIMPULAN}

Dari hasil penelitian dapat diktehui bahwasanya cara menghitung rasio Efektifitas Kota Jakarta yaitu dihitung dengan membagi jumlah realisasi Pendapatan Asli Daerah (PAD) dibagi dengan target PAD yang tempatkan berlandaskan potensi riil pada daerah. yang dimaksud pendapatan asli daerah dapat berupa pajak daerah, pungutan daerah, keuntungan dari pemanfaatan aset daerah yang dipisahkan dan PAD lainnya yang telah diatur. Bersumber pada analisis rasio tentang efektivitas PAD yang ada pada periode 2015-2019 rata-ratanya adalah sebesar 95,4 \%.hal tersebut menunjukan bahwa dalam 5 tahun terakhir kinerja keuangan Kota Jakarta bersumber pada rasio efektivitas PAD masuk dalam kategori efektif, dikarenakan persentasenya berada di kisaran 90\%-100\%. Dan tahun 2017 merupakan tahun yang paling efektif bagi kota Jakarta dalam mengelola keuangan PAD mereka. Meskipun tergolong efektif, Pemerintah Daerah Kota Jakarta harus memperhatikan fluktuasi yang terjadi pada rasio efektifitas selama 5 tahun terakhir tersebut, 
karena meskipun 2015-2017 terus mengalami kenaikan rasio sampai melampaui persentase $100 \%$, tetapi pada 2 tahun terakhir atau 2 tahun terbaru rasio nya terus mengalami penurunan. Oleh karena itu Pemerintah Kota Jakarta di tahun ini dan tahun-tahun berikutnya harus terus meningkatkan kualitas dan kinerja keuangannya terutama dalam mengelola PAD agar kota Jakarta bisa menjadi kota yang Mandiri dan menjadi percontohan kota yang paling efektif dalam mengelola keuangan daerahnya

\section{REFERENSI}

\section{BUKU}

Halim, A., \& Kusufi, M. S. (2007). Akuntansi sektor publik: Akuntansi keuangan daerah. Jakarta: Salemba Empat.

Harun, H. (1990). Penuntun analisis peningkatan dana pembangunan kota. Andi Offset.

Kuncoro, M. (2009). Metode Riset Penelitian Bisnis dan Ekonomi Edisi Ketiga. Penerbit Erlangga. Jakarta.

Mardiasmo. (2002). Otonomi dan manajemen keuangan daerah. Andi.

Munir, D. (2004). Kebijakan \& manajemen keuangan daerah. Yayasan Pembaruan Administrasi Publik Indonesia.

Sugiyono, D. (2004). Metode Penelitian Administrasi, cetakan ketujuh, Bandung: $C V$. Alfabeta.

\section{INTERNET}

Peraturan Menteri Dalam Negeri Nomor 13 Tahun 2013 tentang Kekuasaan Pengelola Keuangan Daerah, Asas Umum, dan Struktur APBD

PPID DKI Jakarta. 2019. Laporan Keuangan Pemerintah Daerah Kota Jakarta 2019. https://ppid.jakarta.go.id/laporan-keuanganpemerintah-daerah

PPID DKI Jakarta. 2015. Laporan Keuangan Pemerintah Daerah Kota Jakarta 2015. https://ppid.jakarta.go.id/laporan-keuanganpemerintah-daerah

PPID DKI Jakarta. 2016. Laporan Keuangan Pemerintah Daerah Kota Jakarta 2016. https://ppid.jakarta.go.id/laporan-keuanganpemerintah-daerah

PPID DKI Jakarta. 2017. Laporan Keuangan Pemerintah Daerah Kota Jakarta 2017. https://ppid.jakarta.go.id/laporan-keuanganpemerintah-daerah

PPID DKI Jakarta. 2018. Laporan Keuangan Pemerintah Daerah Kota Jakarta 2018. https://ppid.jakarta.go.id/laporan-keuanganpemerintah-daerah

Undang-Undang No. 25 Tahun 1999 mengenai Perimbangan Keuangan pemerintah Pusat dan Daerah

Undang-Undang Nomor 33 Tahun 2004 mengenai Perimbangan Keuangan Antara Pemerintah Pusat dan Daerah

Undang-Undang Nomor 34 Tahun 2000 tentang Pajak dan Retribusi Daerah 